\title{
Compromising Immigration Reform: The Creation of a Vulnerable Subclass
}

\author{
Catherine L. Merino
}

The Immigration Reform and Control Act of $1986^{1}$ (IRGA or Act) consists of a series of delicate compromises designed to stop the flow of illegal immigration into the United States. Two major considerations influenced Congress to reform the Immigration and Nationality Act (INA). ${ }^{2}$ First, legislators and their constituents believed that the presence of large numbers of undocumented workers in this country adversely affected the terms of employment for authorized workers ${ }^{3}$ in the United States. ${ }^{4}$ Second, reform proponents argued that the United States had lost control of

1. Immigration Reform and Control Act of 1986, Pub. L. No. 99-603, 100 Stat. 3359 (codified in scattered sections of $8,7,2642$ and 50 U.S.C.).

2. Immigration and Nationality Act of 1952, ch. 477, 66 Stat. 163 (codified as amended in scattered sections of 8 U.S.C.).

3. The Immigration and Naturalization Service (INS) authorizes the employment of various categories of non-citizens, which include, inter alia: lawful permanent resident aliens, aliens admitted or paroled into the United States as refugees, aliens admitted as nonimmigrant fiancés or fiancées, foreign government officials, employces of foreign government officials, and nonimmigrant visitors. Employment Authorization, 8 C.F.R. $\S 109.1$ (a) (1986). In addition, some classes of aliens may be eligible to work, provided that they have applied for and received authorization for employment from the INS. Id., $\S 109.1$ (b) (1986).

4. See, e.g., S. ReP. No. 132, 99th Cong., 1st Sess. 5 (1985) [hereinafter S. REP. 132] (adverse impact of undocumented workers includes both unemployment and less favorable wages and working conditions); Immigration Reform and Control Act of 1983: Hearings on H.R. 1512 Before the Subcomm. on Immigration, Refugee and International Law of the House Comm. on the Judiciary, 98th Cong., 1st Sess. 964 (testimony of Rep. Coelho) ("With unemployment exceeding 10\%, the American people are demanding that we impose . . . control over immigration."); Legalization of Illegal Immigrants: Hearing Before the Subcomm. on Immigration and Refugee Policy of the Senate Comm. on the Judiciary, 97th Cong., 2d Sess. 6 (1981) [hereinafter 1981 Senate Hearings] (testimony of Doris Meissner, Acting Commissioner, INS) ("[M]igrants do useful work . . . but also compete with or at least affect adversely the wages and working conditions of some American workers in some occupations and locations.").

For a discussion of the competing theories regarding the effect of illegal immigration on the workplace in the United States, see Immigration Reform and Control Act of 1985: Hearings on S. 1200 Before the Subcomm. on Immigration and Refugee Policy of the Senate Judiciary Comm., 99th Cong., 1st Sess. 72 [hereinafter 1985 Senate Hearings] (Attachment A to statement of Raul Yzaguirre, National Council of La Raza). According to one school of thought, employment of illegal aliens results in widespread displacement of legal workers. Those in the opposing school argue that the labor market is segmented, with undocumented workers taking only those jobs legal workers refuse to perform. See General Accounting Office, Pub. No. GAO/PEMD-88-13BR, Influence of Illegal Aliens ON WAGes AND Working Conditions of Legal Workers 19, 27 (1988) [hereinafter GAO, INfluence of Illegal. Aliens]; see also Lopez, Undocumented Mexican Migration: In Search of a Just Immigration Law and Policy, 28 UCLA L. REv. 615, 630-38 (1981) (comparing theories regarding impact of employment of aliens). 
its borders and that the influx of large numbers of illegal immigrants threatened national sovereignty. ${ }^{\mathrm{s}}$

Congress hoped to achieve its goal of immigration reform through legalization, employer sanctions, and increased enforcement at United States borders. ${ }^{6}$ Legalization, which adjusted the status of undocumented aliens already living and working in the United States, was intended to reduce the size of a large and vulnerable underclass. ${ }^{7}$ Applicants for legalization who could prove they had resided in the United States since before January 1,1982 qualified to apply for temporary, and later permanent, resident status. ${ }^{8}$

Proponents of employer sanctions argued that the elimination of jobs attracting undocumented aliens would stop the flow of illegal immigration. ${ }^{2}$ The sanctions include civil and criminal penalties for the knowing employment of unauthorized workers. ${ }^{10}$ In order to avoid sanctions, employers must verify employment eligibility for all persons hired after November $6,1986.11$

This Note focuses on the effect of immigration reform on the employ-

5. H.R. REP. No. 682, pt. 1, 99th Cong., 2d Sess. 46, reprinted in 1986 U.S. Cone CoNG. \& ADMIN. News 5649, 5650 [hereinafter 1985 H.R. REP. 682] (quoting testimony of Attorncy General Edwin Meese III at the 1985 Hearings on H.R. 3080 Before the Subcomm. on Immigration, Refugees, and International Law of the House Comm. on the Judiciary, 99th Cong., 1st Sess., Serial No. 28 at 4). See also 132 Cong. Rec. H9710 (daily ed. Oct. 9, 1986) (statement of Rep. Rodino); 131 Cong. Rec. S11,265 (daily ed. Sept. 11, 1985) (statement of Sen. Grassley).

6. The IRCA includes increased appropriations for the INS, which enforces the nation's immigration laws. Congress authorized additional appropriations for the INS of $\$ 422$ million for fiscal year 1987 and $\$ 419$ million for 1988. IRCA $\$ 111(\mathrm{~b})(1)$. Despite the congressional authorization, President Reagan requested only an additional $\$ 138$ million for 1987 and $\$ 122.8$ million for 1988 for enforcement. 64 INTERPRETER ReLEASEs 29, 30 (Jan. 12, 1987).

7. Select Commission on Immigration and Refugee Policy, U.S. Immigration Policy AND the National Interest 72 (1981) [hereinafter U.S. Immigration Policy]. For a discussion of the origins of the Select Commission, see infra note 27 .

Cf. S. REP. 132, supra note 4, at 16 (one purpose of legalization was to eliminate "a fearful and clearly exploitable group within the United States society").

8. 8 U.S.C. $\$ 1255$ a (Supp. IV 1986). Applicants for legalization had to show means of financial support. They were also excludable, as are other immigrants, for reasons enumerated in the INA, $\S$ 241(b), 8 U.S.C. \$ 1251(b) (1982). The legalization application period ended May 4, 1988.

9. See, e.g., S. REP. 132, supra note 4, at 1 (primary incentive for illegal immigration is availability of employment in United States); Immigration Control and Legalization Amendments: Hearings on H.R. 3080 Before the Subcomm. on Immigration, Refugees and International Law of the House Comm. on the Judiciary, 99th Cong., 1st Sess. 4 (1985) [hereinafter 1985 House Hearings] (testimony of Attorney General Edwin Meese III):

Much illegal immigration is caused by the easy entry of illegal immigrants into jobs that are very attractive when compared to employment opportunities in their homelands. Through a provision making it illegal to knowingly hire aliens who lack authorization to work in the United States, this problem can be addressed effectively.

10. 8 U.S.C. $\$ 1324 a$ (Supp. IV 1986). Prior to the IRCA, although unlawfully present immigrants committed a crime by entering the country, employers could hire the same immigrants without breaking the law. 8 U.S.C. \$ 1324(a) (1982). IRCA repealed this provision, known as the Texas proviso. With the passage of the Act, an employer is subject to a civil penalty from $\$ 250$ to $\$ 2000$ for a first violation, from $\$ 2000$ to $\$ 5000$ for a second violation, and up to $\$ 10,000$ for any subsequent violations. Control of Employment of Aliens, 8 C.F.R. $\$ 274 a .10$ (1988). Those who engage in a pattern or practice of employing unauthorized aliens are subject to criminal penalties of up to $\$ 3000$ for each unauthorized alien, imprisonment for up to six months, or both. Id.

11. 8 U.S.C. $§ 1324 a$ (1) (Supp. IV 1986). 
ment rights of one subclass of undocumented workers, ${ }^{12}$ those who arrived in the United States after January 1, 1982, the Act's legalization eligibility date, but prior to November 6, 1986, the Act's effective date. ${ }^{13}$ Some members of this subclass have children who are United States citizens, family members who are legal residents, and strong community ties. Consequently, many immigrants in this subclass have not left the United States although they are unable to adjust their status. ${ }^{14}$ When it passed the Act, Congress failed to consider adequately the large numbers of undocumented persons who would remain in the United States despite the implementation of employer sanctions, ${ }^{15}$ and the impact of the presence of such a class on the enforcement of employment laws in the United States.

Unauthorized employees in the 1982-1986 subclass find themselves in a particularly vulnerable position relative to both legalized aliens and post-

12. The new law is expected to affect employment rights of all workers and increase labor and employment litigation. Kobdish, The Frank Amendment to the Immigration Reform and Control Act of 1986-A Labyrinth for Labor Law Litigators, 41 Sw. L.J. 667 passim (1987); Ross, SimpsonRodino: A Closer Look, CAL. LAW., Apr. 1987, at 51. Authorized workers receive some protection from IRCA's anti-discrimination provisions. See infra text accompanying notes 67-76.

13. Estimates vary as to the number of immigrants who entered after 1982 but began working before November 6, 1986. Passel, Undocumented Immigration, 487 ANNals 181, 184 n.2 (Sept. 1986). See also Braun \& Hernandez, Amnesty's Long Term Impact Still Not Clear, L.A. Times, Nov. 15, 1987, at 1, col. 3. The INS originally told Congress that it expected up to 3.9 million legalization applicants. The Alien Amnesty Deadline Should be Extended, Christian Sci. Monitor, Apr. 11, 1988, at 12, col. 1. In July, immigration officials reported that 2.5 million applied for legalization. 2.5 Million Seek Amnesty, L.A. Times, July 11, 1988, at 2, col. 6. Most.of these immigrants plan to stay in the United States, and remain in the labor market. Hoffman, 40 Percent Not Seeking Citizenship, Dallas Times Herald, Dec. 20, 1987, at A-22, col. 1.

14. Arocha, Illegal Immigrants Decide to Stay Put, Wash. Post, July 11, 1988, at D1, col. 6. See also Kamiya \& Kalka, Immigrants' Fear Heightens Today, N.Y. Times, Sept. 1, 1987, at A23, col. 1 ("Few undocumented people will have the option of returning to their home countries, which they left because of poverty, war and repression, and a desire to seek a better life in the United States-at any cost."). See also Corchado \& Solis, Immigration Law Creates a Subclass of Illegals Bound to Their Bosses and Vulnerable to Abuses, Wall St. J., Sept. 2, 1987, at 44, col. 1 (aliens present in United States at time of IRCA's passage who do not qualify for legalization face depressed wages and substandard working conditions).

An economic analysis illustrates why the 1982-1986 subclass would find it beneficial to remain in the United States. The decision to migrate to the United States reflects the fact that the anticipated difference in wages outweighs the costs of immigration (migration costs plus job search costs). $D$. North \& R. Miller, The Economics of Public Issues 124 (5th ed. 1980). Members of this subclass have paid the migration costs already. Although sanctions may increase job search costs somewhat for exempt aliens, a return to their countries of origin would involve new migration costs as well as job search costs. As long as they can find work here at wages comparable to or better than those offered in the origin countries, these aliens will remain in the United States.

15. In testimony before the Senate in 1981, Doris Meissner, Acting Commissioner of the INS, stated, "Certainly, some illegal aliens will go home-not just those lacking the continuous residence requirement." 1981 Senate Hearings, supra note 4, at 10.

In February, 1988, the Carnegie Endowment for International Peace published a report on the implementation of IRCA. D. Meissner \& D. PAPAdemetriou, The Legalization Countdown: A Third-Quarter Assessment (Carnegie Endowment for International Peace, 1988) [hereinafter CARNEGIE REPORT]. Even with optimistic estimates regarding applications still to be received, the authors predicted that the illegal population, consisting of the 1982-1986 subclass and those eligible for legalization who did not apply, would be almost twice the size of the legalized population. This finding led to debates regarding whether to extend the legalization deadline. See The Alien Amnesty Deadline Should Be Extended, supra note 13; Applebome, The Amnesty Gamble: Immigration Law's Impact Still Tough to Measure, N.Y. Times, Mar. 13, 1988, § 4, at 4, col. 1. 
1986 illegal entrants. Section 101(a)(3)(A) of the IRCA provides that employers do not have to check work authorization for any person hired before the enactment of the law. ${ }^{18}$ Thus, these employees are exempt ${ }^{17}$ from the authorization provisions if they retain the jobs they had when the IRCA became law.

Most employers will now request work authorization before hiring. ${ }^{18}$ Under the present system, it is likely that an employer willing to hire an unauthorized worker will adjust wages and working conditions downward to compensate for potential fines. ${ }^{19}$ Thus, exempt aliens face the option of remaining with their pre-1986 employers or accepting substandard terms offered by those who will hire them despite the threat of sanctions.

In addition, the fact that exempt aliens have built up ties in the United

16. See supra note 10 .

17. This Note refers to those in the 1982-1986 subclass as "exempt aliens." These persons are still unlawfully present in the United States. They are, however, exempt from the work authorization provisions with regard to one employer only.

18. Cf. Emigrés Take Risk, Seek Asylum in Large Numbers, L.A. Times, June 24, 1988, pt. 1 at 2, col. 5. (Central Americans increasingly taking risky step of applying for political asylum as it becomes more difficult to find work without documentation). But cf. Piore, The "Illegal Aliens" Debate Misses the Boat, Working PAPERS For a New SOCIETy 60 (Mar./Apr. 1978) reprinted in Cong. Research Serv., 9úth Cong., 2d Sess., Selected Readings on United States Immigration Policy and Law 39 (Comm. Print 1980) [hereinafter Selected Readings]:

Extralegal immigration seems to reflect the fact that legal immigration quotas don't let in as many immigrants as the American economy needs . . . .

Industrial societies seem systematically to generate a variety of jobs that full-time, native-

born workers either reject out of hand or accept only when times are especially hard.

While some employers continue to use illegal alien labor in spite of sanctions, others face increased administrative costs as a result of the Act. The IRCA creates a great burden on all employers, not simply those in industries known for hiring undocumented workers. See Hearing Before the Subcomm. on Regulation and Business Opportunities of the House Committee on Small Business, 100th Cong., 1st Sess. 31 (1987) (testimony of Virginia Thomas, attorney, U.S. Chamber of Commerce) (estimating cost of implementing IRCA at $\mathbf{\$ 1 0}$ per hiring transaction). See also Immigration Reform and Control Act: Hearings on S. 529 Before the Subcomm. on Immigration and Refugee Policy of the Senate Comm. on the Judiciary, 98th Cong., 1st Sess. 48 (1983) (statement of Robert Thompson, Chairman, U.S. Chamber of Commerce) (recommending enforcement targeted at employers who knowingly violate the law).

19. There is ample evidence that employers are still in the market for unauthorized workers. In October, a Department of Labor survey found that only one-third of the businesses in the United States had complied fully with IRCA. Braun \& Hernandez, supra note 13 . The University of California at San Diego Center for United States-Mexico Studies, conducting research on compliance, discovered that some employers are circumventing the law. Some Firms Dodge Law on Immigration, Study Finds, L.A. Times, Jan. 15, 1988, pt. 1 at 3, col. 1.

Felix Cardona, an attorney for the Center for Immigrants' Rights, also testified that sanctions had not deterred employers from employing undocumented aliens. Public Hearing on the Impact of Employer Sanctions in New York, Nov. 2, 1987 (testimony of Felix Cardona, staff attorney, Genter for Immigrants' Rights) (transcript on file at the Yale Law Journal) [hereinafter Cardona Testimony-Employer Sanctions]. Cf. D. NoRTH \& R. Mrli.ER, supra note 14, at 127:

It would be virtually impossible to prevent emplayers from taking advantage of lower-priced, sometimes more productive workers who happen to be illegal aliens. Indeed, most employers using illegals claim they are "better" workers, that is, that they have a higher marginal product [which] results from their desperate need of work. In short, without a total police state, we won't be able to prevent employers from hiring illegals.

See generally Tobar, Immigration Reform Backfires: No Rights for Migrant Workers, THE NATION, Sept. 19, 1988, at 196 (IRCA, by producing desperate class of workers willing to accept increasingly substandard wages and working conditions, has created incentives for employers to hire undocumented workers). 
States renders them more vulnerable than post- 1986 entrants. ${ }^{20}$ It may be impractical or entirely impossible for members of the subclass to return to their countries of origin. Even if they wished to do so, moreover, unauthorized aliens may not be able to pay for transportation home. Voluntary surrender to the INS is not a viable option, because deportation carries serious, life-long consequences. Deportation can bar subsequent legal entry to the United States, ${ }^{21}$ result in summary deportation proceedings for a later attempted illegal re-entry, ${ }^{22}$ or lead to felony prosecution for a later illegal re-entry. ${ }^{23}$ Unwilling to risk deportation by protesting illegal conditions, exempt employees are particularly unlikely to enforce their employment rights. ${ }^{24}$

This Note argues that the IRCA should be amended to allow members of the 1982-1986 subclass to legalize their status. The IRCA has not eliminated the illegal workforce, a primary goal of immigration reform. Instead, exempt aliens have become an even more exploited workforce. ${ }^{25}$ To remedy this problem, Congress should change the legalization eligibility date to November 6,1986, the date of the IRCA's passage, in order to allow this vulnerable subclass to claim the full protection of the nation's employment laws. The proposed amendment of the IRCA would secure the goals of immigration reform, including protection of all workers' employment rights.

Section I examines the origins and purposes of the legalization provisions. It then discusses the compromise that led to the 1982 legalization eligibility date. Section II explains the reasons that the IRCA, in its present form, will necessarily result in increased employment practice discrimination. ${ }^{28}$ This discussion includes an examination of the employment rights of exempt aliens after the IRCA and the ineffectiveness of the law's anti-discrimination provisions for protection of the 1982-1986 subclass. Finally, Section III discusses the condition of the exempt alien in the employment market. This Section, while acknowledging the delicate political compromise that led to the IRCA, recommends that Congress re-visit its decision to establish a legalization eligibility date of 1982 .

20. The INS recognizes the difficulties of families with some members who qualify for legalization and others who do not. Although the INS refused to promulgate an across-the-board rule, it will consider family situations in deciding whether to grant voluntary departure in lieu of deportation. Adjustment of Status for Certain Aliens, 52 Fed. Reg. 16,205, 16,207 (proposed May 1, 1987).

21. 8 U.S.C. $\$ \S 1182(\mathrm{a})(16)-(17)(1982)$.

22. 8 U.S.C. $\S 1252(\mathrm{f})(1982)$.

23. 8 U.S.C. $\S 1326$ (1982).

24. See infra note 39 and accompanying text.

25. Corchado \& Solis, supra note 14; Kamiya \& Kalka, supra note 14; supra text accompanying note 20. See Brown, Economic Serfdom, 32 Boston BAR J., Mar./Apr. 1988, at 14, 14:

There are reliable reports that many forms of enslavement are beginning to proliferate. In one case, a disguised headhunter confessed that for many months prior to adoption of [IRCA], he obtained a $\$ 100$ fee for each illegal alien he succeeded in bringing to employers. The latter were avid to pay him for obtaining such [exempt alien] prizes.

26. For the definition of employment practice discrimination, see infra note 65 . 


\section{History of the Legalization Provisions}

\section{A. The Select Commission Report}

Discussion of the IRGA's legalization provisions did not begin with the 1985 congressional debates on immigration reform. Five years before enactment of the IRCA, the Select Commission on Immigration and Refugee Policy submitted its final report to Congress, recommending that a legalization program be established. ${ }^{27}$ The Commission emphasized that legalization "should be consistent with U.S. interests" and "should not encourage further undocumented migration."28 The Select Commission recommended a legalization eligibility date of January $1,1980 .^{29}$ The Commission avoided an earlier cutoff date because such a date "would permit the participation of too few undocumented/illegal aliens, leaving the United States with a substantial underclass still in illegal status $\ldots . .^{30}$ On the other hand, the Commission did not select an eligibility date later than the release of its report, fearing that such a recommendation would encourage increased illegal immigration. ${ }^{31}$ The Commission also refused to suggest a specific length of residency requirement. Unable to predict how quickly the legislature would act, the Commissioners believed that Congress would be better equipped to set the residency requirement. ${ }^{32}$ The Commission did offer guidelines for determining the term of years required, recommending that Congress "balance[] the desire for incorporating a substantial number of undocumented/illegal aliens into U.S. society with the necessity of limiting that participation to those who have acquired some equity in this country."

Congress, in passing the IRCA, did not adequately balance these two competing interests. The 1982 legalization date effectively imposed a four year residency requirement that prevented a large portion of the undocumented population from incorporating into the mainstream. Consequently, a substantial underclass remains in the United States in contradiction of Congress' original goals of immigration reform.

\section{B. Legalization of Status}

Given the desirability of eliminating the category of people working in the United States without legal protection, ${ }^{34}$ Congress included legaliza-

27. U.S. Immigration Policy, supra note 7, at 72. Public Law No. 95-412 established the Commission, with duties that included the submission of a report to Congress evaluating existing immigration laws and policies and the proposal of legislative and administrative amendments. Act of Oct. 5, 1978, Pub. L. No. 95-412, § 4(d), 92 Stat. 907, 908.

28. U.S. Immigration Policy, supta note 7 , at 75 .

29. Id. at 76 .

30. Id. at 77 .

31. Id.

32. Id. at 78 .

33. Id.

34. Cf. 1985 H.R. REP. 682, supra note 5, at 49, reprinted in 1986 U.S. CODE CoNG. \& AD- 
tion provisions in its immigration reform legislation. Legalization applicants had to submit evidence to the INS proving identity, continuous residence prior to 1982, and means of financial support. ${ }^{35}$ Aliens who qualified for legalization received authorization to work in this country.

Legalization was designed to complement employer sanctions in eliminating the illegal workforce in the United States. ${ }^{36}$ Some legislators viewed legalization as the only just and effective way to remove the large class of undocumented workers living here. Congress accepted the Select Commission's finding that "[a]ttempts at massive deportation would be destructive of U.S. liberties, costly, likely to be challenged in the courts and, in the end, ineffective." In In addition, some members of Congress felt that the presence of undocumented workers resulted in large part from the action (or inaction) of the United States government itself. ${ }^{38}$

Witnesses also testified repeatedly that undocumented workers appeal to employers precisely because they will not report working conditions and employment arrangements that violate federal and state statutes. ${ }^{30}$ Representative Rodino summed up the vulnerable position of the undocumented worker: "[U]ndocumented persons must keep all contacts with governmental authorities to an absolute minimum . . . When their employer short changes them or doesn't pay them for overtime, or pays them less than minimum wage, they will complain to no one." ${ }^{310}$

Members of Congress realized that the existence of a shadow population and a subterranean economy ${ }^{41}$ is harmful to both legal workers and aliens unlawfully present in the United States. Some witnesses and legislators maintained that the presence of undocumented workers leads to

MIN. NEwS at 5653 (legalization "would allow qualified aliens to contribute openly to society and it would help to prevent the exploitation of this vulnerable population in the work place").

35. Adjustment of Status for Certain Aliens, 8 C.F.R. § 245a.2(d) (1988).

36. See infra note 49.

37. U.S. IMMIGRATION PolICY, supra note 7, at 73; see 1985 H.R. REP. 682, supra note 5, at 49, reprinted in 1986 U.S. CODE CONG. \& ADMIN. NEwS at 5653 ("[A]ttempting mass deportations would be . . costly, ineffective, and inconsistent with our immigrant heritage.").

38. For example, the Texas proviso of the INA exempted employers from penalties for harboring aliens. See supra note 10. In addition, the Bracero program legitimized the use of foreign labor in agriculture. See infra notes 78-79 and accompanying text; see also U.S. IMMIGRATION POLICY, supra note 7, at 74:

Some Commissioners also believe that legalization would acknowledge that the United States has at least some responsibility for the presence of undocumented/illegal aliens in this country ... Some Commissioners also argue that because of that partial responsibility, the alternatives to legalization-continuing largely to ignore undocumented/illegal aliens or initiating mass deportation efforts-would, apart from being harmful to the United States, constitute unfair penalties on aliens and their families.

39. See, e.g., 1985 House Hearings, supra note 9, at 64 (testimony of Thomas R. Donahue, Secretary-Treasurer, AFL-CIO); at 76 (statement of Archbishop (then Bishop) Anthony J. Bevilacqua); at 93 (statement of Dale De Haan, Director, Church of World Service).

40. 132 Cong. Rec. H9709 (daily ed. Oct. 9, 1986) (statement of Rep. Rodino).

41. See, e.g., 131 Conc. Rec. S11,429 (daily ed. Sept. 13, 1985) (statement of Sen. Kennedy) ("There is no question [that] there is a subterranean economy with extraordinary exploitation and all the implications that has for our own society."). 
higher unemployment. ${ }^{42}$ The United States Catholic Conference, in a prepared statement, observed that "competition is indirect, as when aliens willingly accept the wages and conditions offered by employers [which] domestic workers, with their higher expectations, do not or believe they cannot accept."33 Many employers prefer to hire undocumented workers because it costs more to hire a legal employee, who will not hesitate to invoke her employment rights; this results in increased unemployment for authorized workers. ${ }^{44}$ Althea Simmons, Director of the Washington Bureau of the NAACP, testified that "particularly in large cities, . . . the undocumented worker impacts the employment of blacks . . . [T] [Te undocumented worker . . . is hired at a sub-minimum wage and is at the mercy of the employer."'45 Others maintained that unlawfully present aliens adversely affect legal workers' wages ${ }^{46}$ even if the presence of undocumented workers does not lead to increased unemployment. ${ }^{47}$ Thus, concern for the legal rights of authorized workers colored Congress' intent in passing the IRCA. ${ }^{48}$

Supporters of immigration reform argued that stronger border control, combined with legalization and employer sanctions, would sharply reduce the number of unauthorized aliens in the country. ${ }^{49}$ Opponents of legali-

42. See, e.g., 132 Cong. Rec. H9,715 (daily ed. Oct. 9, 1986) (statement of Rep. Smith) (undocumented workers "are today taking the jobs of Americans and getting paid off the books").

43. 1985 House Hearings, supra note 9, at 82 .

44. Undocumented workers are attractive because they are a docile workforce too frightened to report employment law violations. Legalization, by eliminating the illegal status of certain aliens, created a less attractive workforce.

For a discussion of the inadequacy of sanctions in deterring such employment, see supra note i8.

45. 1985 H. REP. 682(I), supra note 5, at 47, reprinted in 1986 U.S. CODE CONG. \& ADMIN. News at 5651 .

46. Some experts theorize that the presence of undocumented aliens harms unskilled, low income laborers while benefitting skilled workers with higher income. See, e.g., Wachter, The Labor Market and Illegal Immigration, 3 INDUS. AND LAB. REL. REv. 342, 351 (1986), reprinted in SELECTED RFADINGS, supra note 18, at 21 (arguing that presence of illegal aliens harms domestic unskilled workers); Chiswick, Illegal Immigration and Immigration Control, 2 J. ECON. PERSP. 101, 106-107 (1988) (citation omitted):

The entry into the labor force of additional low-skilled workers . . . depresses the marginal productivity of all low-skilled workers [which] generally translates into lower wages. However, it may also lead to a decrease in the employment of native workers . . . .

The increased immigration of low-skilled workers will lead to an increase in the marginal productivity and hence the wage rate of higher-skilled workers and the return on capital .... [T] he losses to native low-skilled labor are more than offset by the gains to native high-skilled labor and capital.

A recent General Accounting Orfice report confirms this theory. GAO, InfLueNCe of Illegal Aliens, supra note 4 at 19. 27.

47. See supra note 45 and accompanying text.

48. Cf. U.S. Immigration Policy, supra note 7, at 72: "The costs to society of permitting a large group of persons to live in illegal, second-class status are enormous. Society is harmed every time an undocumented alien is afraid to . . . disclose a violation of U.S. labor laws."

49. Senator Kennedy stated, "[T]he fundamental principle upon which this legislation has always been based ... requir[es] that we move simultaneously on: First, the new enforcement provisions; second, implementation of employer sanctions; and third, the institution of a legalization program." 131 Conc. Rec. S1 1,428 (daily ed. Sept. 13, 1985).

Increased enforcement was considered essential. As Senator Simpson observed, "Legalization in the absence of more effective enforcement is very likely to increase the illegal flow." 131 ConG. REc. 
zation argued, however, that granting legal status to undocumented aliens would hinder enforcement by encouraging further illegal immigration. The opposition also regarded legalization as a reward for those who had broken the law. ${ }^{\text {so }}$ The outcome of this political stalemate, a 1982 legalization date, failed to "wipe the slate clean," a necessary element of immigration reform.

Although some legislators ${ }^{52}$ and many witnesses observed that a 1982 date for legalization eligibility would still leave a substantial subclass who would not qualify, ${ }^{\text {s3 }}$ opposition to a later date was strong enough to overcome those arguments. As the following Section illustrates, the acceptance of the 1982 date and of legalization itself was the result of an intricate but ultimately destructive political compromise. ${ }^{54}$

Although politically expedient, the compromise produced a law which cannot fulfill one of its own purposes: namely, the elimination of the vulnerable status of undocumented employees whose position in the labor force adversely affects legal workers' employment conditions. The combination of a 1982 legalization date and the imposition of employer sanctions in $1986^{\mathrm{Bb}}$ created the fatal flaw in IRCA. Legislators made a critical error in either assuming that most of the exempt subclass would leave after the implementation of employer sanctions or ignoring the issue alto-

S11,429 (daily ed. Sept. 13, 1985). See supra note 6 for a discussion of increased appropriations for enforcement.

50. 132 Cong. Rec. H9727 (daily ed. Oct. 9, 1986) (statement of Rep. Daub).

51. 131 CoNG. REC. S11,428 (daily ed. Sept. 13, 1985) (statement of Sen. Kennedy) ("As we institute new enforcement policies, legalization allows us to wipe the slate clean, to deal humanely and responsibly with the problems of the past as we begin to deal more effectively with future illegal migration."); see also 1985 Senate Hearings, supra note 4, at 33 (testimony of Michael Teitelbaum, Program Officer, Alfred P. Sloan Foundation) (Iegalization seen as way to eliminate social underclass); 1985 House Hearings, supra note 9, at 94 (statement of Dale DeHaan, Director, Church of World Service) (intent of legalization program, "to wipe the slate clean," requires later cutoff date).

52. See infra note 63 and accompanying text.

53. See, e.g., 1985 House Hearings, supra note 9, at 57 (testimony of Thomas R. Donahue, Secretary-Treasurer, AFL-CIO) (urging eligibility date of one year before enactment); at 74 (statement of Archbishop Bevilacqua) (proposing cutoff date of 1983); at 88 (statement of Hyman Bookbinder, Representative of the American Jewish Comm.) (same); at 94 (statement of Dale De Haan, Director, Church of World Service) (suggesting more current cutoff); at 99 (joint statement of International Jewish Migration Agency and Lutheran Immigration and Refugee Service) (same); at 118 (statement of National Council of La Raza) (recommending date of 1983); at 160 (statement of NAACP) (supporting eligibility as of date of enactment).

54. One commentator noted that "[s]upporters of [IRCA] were also aided by . . . the weariness of some of the bill's opponents. Hispanics and business representatives, believing passage was inevitable, devoted their efforts to tailor the legislation more to their liking." Comment, The United States Immigration Reform and Control Act of 1986: A Critical Perspective, 8 Nw. J. INr'L L. \& Bus. 503, 503 n.1 (1987) (citations omitted).

Doris Meissner, former Acting Commissioner of the INS, noted that the IRCA "resulted from a political compromise, not a real analysis, and we'll have to live with the deficiencies of that approach." Applebome, Amnesty for Aliens: The Curtain Rings Down to Some Mixed Reviews, N.Y. Times, May 7, 1988, $\$ 1$, at 7, col. 1 .

55. Concerns regarding the effect of the law on American businesses and authorized workers motivated the IRCA's prospective application. See, e.g., 1985 H.R. REP. 682, supra note 5, at 56, reprinted in 1986 U.S. CODE CONG. \& ADMIN. NEwS at 5660 ("The Committee felt Iprospective application] would be the least disruptive to the American businessman and would also minimize the possibility of employment discrimination."). 
gether. ${ }^{58}$ Instead, exempt aliens remained in the United States, ${ }^{57}$ unprotected against employer abuse. For this reason, Congress should reexamine the legalization eligibility cutoff.

\section{G. Congressional Consideration of the Legalization Date}

The legislative debates surrounding the IRCA reflect the intensity of disagreement regarding the appropriate date for legalization eligibility. ${ }^{\mathbf{s}}$ In 1984, the House considered a predecessor bill to H.R. 3080, which became the IRCA. When faced with attempts to restrict eligibility, many representatives supported the House committee's proposed date of 1982. Congressman Rodino argued:

If we do not preserve the legalization formula in the committee bill, we will be condemning unknown millions of hard-working, lawabiding people--and their children - to an inhumane existence, with the constant dread of discovery and the protection of our laws denied them..$^{30}$

Yet, as Congress reconsidered immigration reform in subsequent years, the legalization eligibility date did not change. In 1983, the Senate immigration bill had an eligibility date of $1980{ }^{60}$ In 1985 , the Senate bill still went to conference with a date of $1980,{ }^{61}$ despite the fact that two more years had passed with aliens entering the country illegally. Those who opposed the early eligibility date were forced to accept 1982 or risk jeopardizing legalization altogether. ${ }^{62}$ The IRCA's supporters believed that the existence of the exempt subclass was less objectionable than the passage of employer sanctions without any legalization provision. ${ }^{63}$ The existence of substantial political opposition ${ }^{64}$ to any type of legalization program increased the pressure to compromise.

56. 132 Cong. Rec. H9715 (daily ed. Oct. 9, 1986) (statement of Rep. McCollum).

57. See supra note 15.

58. See, e.g., 130 CoNG. Rec. H6032-60 (daily ed. June 19, 1984) (debate surrounding amendment proposed by Rep. Lungren).

59. Id. at $\mathrm{H} 6043$.

60. S. ReP. No. 62, 98th Cong., 1st Sess. 19 (1983).

61. S. REP. 132, supra note 4 , at 15 .

62. See supra note 54 .

63. Senator Kennedy, a proponent of a later eligibility date, observed:

This legalization program makes sense from a practical point of view. It is really the most practical way that we can take a subclass, limited certainly, as I have pointed out in earlier debates, but at least a part of the subclass of undocumented aliens, and bring them into the mainstream of American life . . . .

129 Cong. Rec. $\$ 6723$ (daily ed. May 16, 1983) (emphasis added).

Senator Kennedy supported a generous and flexible legalization program. S. REP. 132, supra note 4, at 103 (minority view of Mr. Kennedy). See also 131 Cong. REC. S11,428 (daily ed. Sept. 13, 1985) ("IT]he only sensible way to deal with this issue is to follow the Select Commission's recommendation that we move simultaneously on new enforcement strategies at the same time we also clean up the mess current law has created in a large population of undocumented aliens.").

64. Representative McCollum summed up the argument against legalization, citing four reasons 


\section{Exempt Employees and Employment Practice DISCRIMINATION $^{65}$}

This section examines the vulnerability of exempt workers and the possibility of increased employer violation of labor laws. The first subsection analyzes the IRCA's anti-discrimination provisions, which redress only hiring discrimination. The next subsection develops an analogy between exempt employees and the highly exploited Bracer $^{68}$ workers, illustrating that exempt employees are especially vulnerable to employment practice discrimination. The third subsection examines how unlawfully present aliens are chilled from enforcing their employment rights.

\section{A. The Limited Scope of the IRCA's Anti-Discrimination Provisions}

Anticipating the effect that employer sanctions might have on authorized workers who look or sound foreign, ${ }^{67}$ the IRCA includes antidiscrimination provisions $s^{68}$ to address potential increased discrimination in hiring. While denying that the IRCA would lead to wholesale discrimination in hiring without such provisions, ${ }^{89}$ the House Judiciary Committee emphasized that it had taken "every effort . . . to minimize the potentiality of discrimination . . . ."70

for his opposition. First, amnesty "would be a slap in the face to the millions who have stood in line around the world for years waiting to come to this country legally." Second, legalization would act as a magnet for future illegal migration. Third, the proposed law would result in a great distortion in immigration patterns, with certain regions of the world getting more than their proportional share of immigrants to the United States. Finally, legalization would lead to increased costs to taxpayers. 130 ConG. Rec. H6044 (daily ed. June 19, 1984).

65. Employment practice discrimination is an employer's systematic imposition of substandard terms on a particular group of workers.

66. "Braceros" were temporary agricultural workers imported from Mexico. See infra text accompanying notes 78-79.

67. The IRCA's legislative history contains substantial discussion of the potential for increased hiring discrimination as a result of sanctions. Alien Adjustment and Employment Act, 1977: Hearings on S. 2252 before the Senate Comm. on the Judiciary, 95th Cong,, 2d Sess. 48 (1978) (testimony of Vilma Martinez, president of Mexican-American Legal Defense and Education Fund (MALDEF)); 1985 House Hearings, supra note 9, at 64 (testimony of Thomas Donahue, SecretaryTreasurer, AFL-CIO). See also 1985 Senate Hearings, supra note 4, at 81 (National Council of La Raza Report, attachment B) (sanctions will have adverse impact on hiring decisions affecting Hispanic and other "foreign-looking" workers). But see Anti-Discrimination Provision of H.R. 3080: Hearings before the Subcomm. on Immigration and Refugee Policy of the Senate Comm. on the Judiciary, 99th Cong., 2d Sess. 208 (1985) (testimony of Paul Grossman, attorney and co-author, Employment Discrimination Law) (IRCA will not create substantial alienage discrimination).

68. The IRCA established legal redress for hiring discrimination that might result from employer sanctions. 8 U.S.C. $\S 1324 \mathrm{~b}(\mathrm{a})(1)$ states that it is an unfair immigration-related employment practice "to discriminate against any individual (other than an unauthorized alien) with respect to the hiring ... of the individual for employment ... because of such individual's national origin or ... because of such individual's citizenship status." 8 U.S.C. $\$ 1324 \mathrm{~b}(\mathrm{a})(1)$ (subsection letters omitted).

For a discussion of the effectiveness of these provisions, see Comment, IRCA's Anti-Discrimination Provisions: Protection Against Hiring Discrimination in Private Employment, 25 SAN DiEgo L. REv. 405 (1988) (interaction of Title VII, Section 1981, and IRCA will protect likely discriminatees).

69. 1985 H.R. REP. 682, supra note 5, at 68, reprinted in 1986 U.S. CoDE CoNG. \& ADMIN. NEwS at 5672 .

70. Id. 
As a result of these efforts, section 102 of the IRCA ${ }^{71}$ broadens Title VII's coverage of national origin discrimination ${ }^{72}$ and outlaws discrimination based on citizenship status. ${ }^{73}$ The IRGA also empowers a special counsel to consider alleged violations of these provisions, ${ }^{74}$ but Congress also has clearly stated that section 102 does not in any way restrict the powers of the Equal Employment Opportunity Commission. ${ }^{75}$ Finally, the IRCA creates a taskforce to monitor the effects of the law on patterns of discrimination and to initiate legislative retraction upon a finding of widespread discrimination. ${ }^{76}$

These provisions protect authorized workers. The Act does not address the problem of employment practice discrimination aimed at unlawfully present aliens. As the next subsection illustrates, exempt workers are particularly vulnerable to such discrimination. ${ }^{77}$

\section{B. Exempt Employees and Migrant Workers: An Analogy}

The position of exempt employees is analogous to that of the migrant workers under the Bracero program.78 That program led to "widespread abuse of both braceros and 'illegal' Mexican workers, who in some cases became virtual slaves." ${ }^{\prime 2}$ Braceros were bound by contract to a specific farm and could not work legally for any other employer.

Exempt employees are in a similar situation. While able to continue working without authorization for employers who hired them before No-

71. 8 U.S.C. § 1324b (Supp. IV 1986).

72. Title VII of the Civil Rights Act of 1964 applies only to those businesses with 15 or more employees. 42 U.S.C. $\$ 2000 \mathrm{e}(\mathrm{b})$ (1982). The IRCA covers all those employing more than three people. 8 U.S.C. $\$ 1324 b(a)(2)(A)$ (Supp. IV 1986).

73. 8 U.S.C. § $1324 b(a)$ (1)(B) (Supp. IV 1986). Cf. Espinoza v. Farah Mfg. Co., 414 U.S. 86 (1973) (Section 703 of Title VII does not apply to citizenship-based discrimination).

74. 8 U.S.C. $\$ 1324 b(c)(2)$ (Supp. IV 1986).

75. 8 U.S.C. $\S 1324 b(b)(2)$ (Supp. IV 1986).

76. The IRCA requires the Comptroller General to report to Congress annually for three years on the results of the implementation of the law. 8 U.S.C. $\$ 1324 a(j)(1)$ (Supp. IV 1986). A joint taskforce, consisting of the Attorney General, the chair of the Commission on Civil Rights, and the chair of the Equal Employment Opportunity Commission is responsible for reviewing the report. 8 U.S.C. $\$ 1324 a(k)(1)$ (Supp. IV 1986). If the Comptroller General makes a determination that the IRCA has resulted in a pattern of discrimination in employment, the task force must recommend appropriate legislation. 8 U.S.C. § 1324a(k)(2) (Supp. IV 1986). If both houses of Congress enact a joint resolution approving the discrimination finding within 30 days of the report's issuance, employer sanctions will terminate. 8 U.S.C. $\$ 1324 a(1)(1)$ (Supp. IV 1986). IRCA outlines expedited procedures in the House and Senate for consideration of this matter. 8 U.S.C. $\$ \S 1324 \mathrm{a}(\mathrm{m}),(\mathrm{n})$.

Another attempt to monitor legal employment relationships is the requirement that the President report annually to Congress for three years on the implementation of the work authorization provisions, analyzing the impact of those provisions on "the employment, wages, and working conditions of United States workers and on the cconomy of the United States." IRCA § 402(3)(A).

77. See infra text accompanying notes 80-82.

78. The Bracero program began in 1942, pursuant to a treaty with Mexico, as a temporary wartime measure to provide United States farmers with Mexican laborers. The program continued until 1951 through a series of agreements between the United States and Mexico. Congress established the program by statute in 1951. An Act to Amend the Agriculture Act of 1949, Pub. L. No. 78, 65 Stat. 119 (1951). On May 29, 1963, Congress terminated the Bracero program.

79. J. Cockcroft, Outlaws in the Promised Land 68 (1986). 
vember 6, 1986, exempt aliens cannot provide adequate documentation for a new job, ${ }^{80}$ because after the IRGA, most new employers offering standard employment terms will demand to see work authorization. ${ }^{32}$ Agencies that work with the undocumented population have already received reports of employer attempts to profit from this immobility. The Center for Immigrants' Rights in New York has received phone calls from exempt employees who have not been paid for months, because their employers know that they will not risk deportation by looking for new jobs. ${ }^{82}$

The IRCA also included an amendment revising the temporary farmworker program ( $\mathrm{H}-2 \mathrm{~A}$ program $)^{83}$. The debate surrounding $\mathrm{H}-2 \mathrm{~A}$ workers demonstrates the legislature's cognizance of the possibility of unacceptable wages and living conditions resulting from such employment immobility. ${ }^{84}$ The spirited congressional discussion of the $\mathrm{H}-2 \mathrm{~A}$ program centered on whether it would ultimately deteriorate, just as the Bracero program had. ${ }^{85}$ For example, Representative Gonzalez argued that the new program "guarantees that those who want to exploit cheap, foreign labor on farms and ranches can continue to do so with impunity." resentative Panetta argued in opposition that the program would result in higher employment standards. He saw the choice as "protecting [t]he existing system, where we have uncontrolled borders, employers who easily can exploit, workers who can easily be exploited . . . versus a reform bill

80. As a consequence of the IRCA, employers have taken advantage of vulnerable unauthorized aliens by imposing six- and seven-day work weeks, refusing to pay for labor, cutting wages while increasing hours and abusing their employees physically and sexually. Corchado \& Solis, supra note 14. For a description of existing illegal employment practices in New York City's garment industry, see Freitag, New York is Fighting Spread of Sweatshops, N.Y. Times, Nov. 16, 1987 at A1, col. 2. The General Accounting Office recently released a report documenting the resurgence of sweatshops in the garment, restaurant and meat processing industries. Experts attribute this development, in part, to the "large number of immigrants, both legal and illegal, [which] has created a sizable and trained pool of workers who are easily exploited." Investigators Find Sweatshops Are in Resurgence, N.Y. Times, Sept. 4, 1988, at A26, col. 1. See also 1981 Senate Hearings, supra note 4, at 209 (statement of International Ladies Garment Workers Union) (presence of undocumented workers linked to rapid growth of sweatshops in garment industry).

81. See Arocha, supra note 14.

82. See Cardona testimony-Employer Sanctions, supra note 19.

83. 8 U.S.C. $\S 1186$ (Supp. IV 1986). This program makes temporary migrant labor available where no domestic workers are willing to perform the job. Some argue that the claim of domestic labor shortages is fictitious and such a program is unnecessary. See Chavez Steps up Fight on Foreign Labor, L.A. Times, pt. 1 at 2, col. 3.

84. See infra notes 88-90 and accompanying text. An employer must apply to the Secretary of Labor for certification to hire temporary workers. The Secretary may deny the application if the employer has violated a material term of past certification. In addition, the Secretary will not issue certification when there is a strike or a lockout. 8 U.S.C. $\S 1186(b)$ (Supp. IV 1986). Thus, the Secretary polices employer compliance with relevant employment laws.

85. See, e.g., 1985 House Hearings, supra note 9, at 88 (statement of Hyman Bookbinder, D.C. Representative of the American Jewish Comm.) ("temporary labor arrangements deteriorate all too easily into exploitative relationships"); at 129 (statement of Richard P. Fajardo, Acting Assoc. Counsel, Mexican-American Legal Defense Fund) (temporary farmworker program provisions to protect labor rights "unenforceable due to the leverage growers had over farmworkers"); S. REP. 132, supra note 4, at 108 (minority views of Mr. Simon) (citing problems with Bracero program).

86. 132 ConG. ReC. H10,588 (daily ed. Oct. 15, 1986). 
that tries to correct those concerns." ${ }^{18}$ Given the similarity between the expanded guestworker provisions and the infamous Bracero program, the Committee reporting on H.R. 3080 had to distinguish its new proposal.

Mobility was the distinguishing factor. The House Judiciary Committee stated that there were two essential elements for any new guestworker program. "First, the workers must be free to move from employer to employer without risk of negative repercussions. And second, the workers must be fully protected ${ }^{88}$ under all federal, state and local labor laws." ${ }^{889}$ One Representative summed up the importance of the ability to change employers:

[I]t gives the growers their supply of labor, but what it also does is, it says: "Laborer, if that grower decides not to give you a toilet, not to give you running water, to pay you 90 cents an hour, you are no longer stuck .... Y You can, in a sense, vote with your feet."

The exempt subclass does not enjoy that mobility. Formally, exempt aliens have "mobility" and are fully protected by employment law. As a practical matter, however, these guarantees are illusory.

\section{Statutory Employment Rights of Aliens: The Problem of Enforcement}

Exempt employees retain formal employment rights, ${ }^{91}$ but the passage of the IRCA will affect the likelihood of the enforcement of those rights. In Sure-Tan, Inc. $v$. $N L R B,{ }^{92}$ the Supreme Court held that undocumented workers are covered by the National Labor Relations Act. ${ }^{93}$ The Court recognized that congressional attempts to secure minimum standard terms of employment required the application of the NLRA to all workers. If not protected by the NLRA, undocumented aliens present in the United States and not subject to standard terms of employment could adversely affect the employment conditions of lawful employees. ${ }^{94}$ Similarly,

87. Id. at $\mathrm{H} 10,591$.

88. As authorized temporary workers, Braceros technically enjoyed employment protections. In fact, however, the law was not observed. See supra note 85.

89. 1985 H.R. REP. 682, supra note 5, at 51, reprinted in 1986 U.S. CodE CoNG. \& AdMIN. NEwS at 5655 (footnote added).

90. 132 Cong. Rec. H9724 (daily ed. Oct. 9, 1986) (statement of Rep. Schumer).

91. Patel v. Quality Inn S., 846 F.2d 700 (11th Cir. 1988), rev'g Patel v. Sumani Corp., 660 F. Supp. 1528 (N.D. Ala. 1987) (after IRCA, Fair Labor Standards Act continues to cover unlawfully present aliens). See also Comment, Protection for Undocumented Workers Under the FLSA: An Evaluation in Light of IRCA, 25 SAN DIEgo L. REv. 379 (1988).

92. 467 U.S. 883 (1984).

93. National Labor Relations Act of 1947, ch. 120, 61 Stat. 136 (codified at 29 U.S.C. § 151-169). Although protected by the NLRA, undocumented workers have limited backpay remedies. See Casenote, Rights Without a Remedy-Illegal Aliens under the NLRA: Sure-Tan, Inc. and Surak Leather Co. v. NLRB, 27 B.C.L. REv. 407 (1986); Comment, Remedies for Undocumented Workers Following a Retaliatory Discharge, 24 SAN Diego L. REv. 573, 579-80 (1987). But see Hernandez v. M/V Rajaan, 848 F.2d 498 (5th Gir. 1988) (injured undocumented longshoreman entitled to damages based on future wages in United States since he planned to stay).

94. 467 U.S. at 892 : 
courts have construed laws protecting migrant farmworkers ${ }^{95}$ to protect undocumented workers as well. ${ }^{96}$ Analogously, the Occupational Safety and Health $\mathrm{Act}^{87}$ and the Fair Labor Standards Act ${ }^{98}$ should cover unauthorized employees. ${ }^{90}$ Those who fall into the exempt category benefit from such protections, if willing to enforce the law.

Realistically, however, exempt undocumented workers will be reluctant to invoke these laws. ${ }^{100}$ In framing the IRCA, Congress failed to address the problem of the immobility of easily silenced exempt employees. At this time, it appears that the exempt workers will remain in the United States and continue to work. ${ }^{101}$ For this reason, the Act necessarily encourages employment practice discrimination such as FLSA violations, ${ }^{102}$ although exempt aliens are technically protected. Members of the exempt subclass cannot "vote with their feet."10s The IRCA offers no protection to exempt employees vulnerable to abuse after the passage of sanctions.

If undocumented alien employees were excluded from participation in union activities and from protections against employer intimidation, there would be created a subclass of workers without a comparable stake in the collective goals of their legally resident co-workers, thereby eroding the unity of all the employees and impeding effective collective bargaining.

95. See, e.g., Migrant and Seasonal Agricultural Worker Protection Act, Pub. L. No. 97-470, 96 Stat. 2583 (1982).

96. See, e.g., In re Reyes, 814 F.2d 168 (5th Cir. 1987) (Migrant and Seasonal Agricultural Worker Protection Act applicable to citizens and aliens alike and whether alien is undocumented is irrelevant).

97. Occupational Safety and Health Act of 1970, Pub. L. No. 91-596, 84 Stat. 1590 (1982) (codified in scattered sections of $5,7,9,15,20,29,42,43$ U.S.C.).

98. Fair Labor Standards Act of 1938, ch. 676, 52 Stat. 1060 (codified as amended at 29 U.S.C. $\S \S 201-219)$.

99. North, Labor Market Rights of Foreign-Born Workers, Monthly LAB. Rev., May 1982, at 32, 33, quoted in Casenote, supra note 93, at 444.

100. Cf. E. Galarza, Merchants of Labor 223-27 (1964), which explains deterrents to the braceros' organization for better employment conditions. In a position analogous to the braceros, the exempt subclass will have many of the same reasons for remaining silent.

It is also possible that some lower courts outside the Eleventh Circuit will further deter undocumented workers from enforcing their labor rights by following the Patel district court's reasoning:

"Since the employment relationship between an employer and an undocumented alien is hence not illegal under the INA, there is no reason to conclude that application of the NLRA to employment practices affecting such aliens would necessarily conflict with the terms of the INA." $660 \mathrm{~F}$. Supp. at 1532 (quoting Sure-Tan, 467 U.S. at 893). Indeed, an employer in California has used similar reasoning as a defense to a charge of sex discrimination. The case will be heard in April of 1989. Tobar, supra note 19, at 196.

101. Arocha, supra note 14.

In Congressional hearings on the 1990 census, Mayor Edward I. Koch of New York testified that many undocumented aliens have remained, despite their ineligibility for legalization. See Impact of Legalization Process on Counting Undocumented Aliens in Decennial Census: Hearing Before the Subcomm. an Census and Population of the Comm. on Post Office and Civil Service, 100th Cong., 1st Sess. 11 (1987). Mayor Koch observed that the 1982 legalization date created this shadow population. Id. at 9-10. In holding these hearings, Congress acknowledged that a large class of undocumented aliens remain in this country in spite of IRCA.

102. See Patel v. Quality Inn S., 846 F.2d at 704. ("Employers might find it economically advantageous to hire and underpay undocumented workers and run the risk of sanctions under the IRCA."). But see Tobar, supra note 19, at 198 (some Latino workers in California have successfully organized to ensure standard wages and working conditions).

103. See supra text accompanying note 90. 


\section{Proposed Legislative Resolution of the Conflict}

Congress should act immediately to amend the IRCA for three reasons. First, the legalization provisions, in creating an exempt subclass, completely undermine a primary goal of immigration reform. Instead of eliminating a vulnerable shadow population, the IRCA simply pushes it further underground. Second, the considerations that led Congress to adopt a 1982 eligibility date are no longer valid. Third, the existence of the exempt subclass conflicts with the goals of federal employment policy. This Section discusses the rationale for an amendment that would change the date of eligibility to November $6,1986 .{ }^{104}$

\section{A. The Failure of Sanctions and 1982 Legalization}

Given the ineffectiveness of employer sanctions, ${ }^{105}$ the 1982 legalization date defeats a significant goal of immigration reform-the removal of a vulnerable subclass in the U.S. labor market. The 1982 date disqualified large numbers of aliens already settled in the United States at the time of the IRCA's passage. In addition, the legalization program, plagued with problems from its inception, ${ }^{108}$ probably discouraged qualified individuals from applying. ${ }^{107}$ The number of undocumented aliens who applied for legalization of status fell significantly below INS projections. Further, employer sanctions have not eliminated the incentives to hire members of the 1982-1986 subclass. Therefore, to accomplish one important goal of reform, Congress must revise the compromise date to November 6, 1986, thus eliminating a vulnerable subclass. This narrowly tailored proposal is designed only to address the problem of exempt aliens subclass. For this reason, similar amendments will not be necessary in future years.

As time passes, the concerns that motivated opponents of a later eligibility date become less valid. When Congress began serious consideration of

104. This Note does not propose a 1988 date, which would be inconsistent with the purposes of the IRCA. An amendment revising the eligibility date to 1986 will achieve an important goal of the IRCA: the elimination of a vulnerable class of workers that existed at the time of the law's passage. An eligibility date of 1988 might encourage people to enter the country illegally hoping for another legalization program in two years. Such a result would clearly undermine immigration reform.

105. For a discussion of why sanctions fail to deter illegal employment, see Comment, Employer Sanctions for Hiring Illegal Aliens: A Simplistic Solution to a Complex Problem, 6 Nw. J. INT'L L. \& Bus. 203, 204-205 (1984). For an examination of the failure of sanctions in other countries, see generally General Accounting Office, Pub. No. GGD 82-86, Information on The Enforcement of Laws Regarding the Employment of Aliens in Selected Countries (1982). See also supra note 80 .

106. Meissner and Papademetriou cited the following problems: inadequate dissemination of information, shifts in policy, slow application processing, and confusing directions from volunteer immigrant assistance agencies. CARNEGIE REPORT, supra note 15 , at viii-xvi.

107. Id. INS' initial efforts were marked by confusion and constant policy changes. See Debate Continues on Alien Deadline Extension, N.Y. Times, Mar. 27, 1988, $\$ 12$, at 10, col. 3 (New Jersey). [hereinafter Debate Continues]. As the INS gained experience with legalization, however, the program ran more smoothly. The INS could use this experience to re-implement legalization for the 1982-1986 subclass, without duplicating the same problems. 
immigration reform in 1980, many legislators did not want to encourage increased illegal immigration while considering amnesty. ${ }^{108}$ The proposed amendment does not raise such concerns. Since only those who can prove they were here before November 6, 1986 will qualify, an amendment at this time would not stimulate further illegal immigration. The opponents of a later date also argued that only long-term residents should qualify. ${ }^{100}$ This Note's proposal would require that aliens reside in the United States for at least the last two years.

Congress did not want to reward those who entered the country, upon hearing of the passage of a legalization program, with resident status. Although this amendment would allow some unlawfully present aliens to become legal residents, this is not a "reward." Instead, this amendment, like the original legalization program, would represent a commitment to the elimination of substandard employment terms in the United States. The proposed amendment will simply realize the IRGA's original goals more fully by legitimizing the status of aliens who will remain in the United States and continue to work here.

\section{B. The Need to Override the Compromise}

This Note proposes that the legalization date, motivated by political considerations, must be amended to reflect circumstances either unforeseen or unacknowledged by members of Congress. Political expediency led to the adoption of the 1982 eligibility date. ${ }^{110}$ Opponents of the 1982 date were forced to accept the creation of the exempt subclass or receive no legalization program at all.

The situation created by the IRCA conflicts with the goals of a large body of federal and state employment and labor law designed to protect workers. ${ }^{111}$ A primary motivation for immigration reform was the desire to eliminate the adverse impact of unauthorized employment on that policy. ${ }^{122}$ Since the existence of the exempt subclass is a threat to the estab-

108. See, e.g., 132 Cong. Rec. H9727 (daily ed. Oct. 9, 1986) (statement of Rep. Daub).

109. See, e.g., 132 CoNG. REc. H10,584 (daily ed. Oct. 15, 1986) (statement of Rep. Rodino) (legalization does not reward aliens who have been in United States for only short period of time). See also 1985 House Hearings, supra note 9, at 4 (testimony of Edwin Meese III) ("people, having entered this country illegally a substantial number [of] years ago, have set down roots here and become productive members of American society"); at 10 (statement of Rep. Mazzoli) (endorsing longterm resident legalization provision).

110. See supra note 54

111. These laws include the Fair Labor Standards Act, ch. 676, 52 Stat. 1060 (1938) (codified at 29 U.S.C. \$§ 201-219); Occupational Safety and Health Act of 1970, Pub. L. No. 91-596, 84 Stat. 1590 (codified in scattered sections of 5, 7, 9, 15, 20, 29, 42,43 U.S.C.); National Labor Relations Act, ch. 372, 49 Stat. 449 (1935) (codifed as amended at 29 U.S.C. $\$ \S 151-169$ ); Labor Management Relations Act of 1947, ch. 120, 61 Stat. 136 (codified as amended at 29 U.S.C. $\$ \$ 141-144,171-187$ ); Equal Employment Opportunity Act of 1972, Pub. L. No. 92-261, 86 Stat. 103 (codified as amended at 42 U.S.C. $\$ \S 2000 \mathrm{e}-2000 \mathrm{e}-15)$.

112. See 1985 H.R. REP. 682, supra note 5, at 47, reprinted in 1986 U.S. CodE CoNG. \& ADMIN. NEwS at 5651 (quoting NAACP testimony on "starvation" labor conditions imposed in undocumented worker market); 1985 House Hearings, supra note 9, at 171 (testimony of Althea 
lishment of minimum standard employment conditions in the United States, a 1986 legalization date is necessary for truly successful immigration reform.

Although the application deadline has passed, ${ }^{113}$ if Congress acts quickly, the INS will be able to use resources developed for the original legalization program. Pursuant to the IRCA, the Attorney General and the INS spent six months promulgating regulations to create the infrastructure required for legalization. ${ }^{114}$ With legalization experience acquired already and regulations in place, the INS should be able to reimplement the program relatively efficiently.

\section{Conclusion}

In passing the IRCA with a 1982 eligibility date, Congress compromised away meaningful immigration reform. Congress will not achieve the goals of immigration reform if it does not change the legalization eligibility date. A substantial underclass still remains in our society because of the 1982 cutoff date. Indeed, the IRGA has simply exacerbated the problem of a subterranean employment market.

Many members of the exempt subclass have remained in the United States, undermining an important goal of the IRCA. This Note argues that the effect of this subclass on the employment market justifies congressional reconsideration of the legalization eligibility cutoff. Should Congress choose not to act, we must acknowledge the price of that inaction as we "live with the deficiencies"115 of the IRCA's compromise.

Simmons).

113. Congress considered extending the application deadline to November 30, 1988. A Senate filibuster killed the bill. See Debate Continues, supra note 107.

114. IRCA § 201(a), 8 U.S.C. § 1255a(g) (Supp. IV 1986).

115. Applebome, supra note 54 (quoting Doris Meissner, former Acting Commissioner, INS). 